\title{
Moral policy and current affair issues factors in the 2012 US Presidential election speeches
}

\author{
Yu. Zablotskyi \\ National University of Ostroh Academy \\ Corresponding author: E-mail: yurii.zablotskyi@oa.edu.ua
}

Paper received 28.03.19; Accepted for publication 11.04.19.

https://doi.org/10.31174/SEND-Ph2019-195VII59-20

\begin{abstract}
The article analyses 2012 US Presidential campaign regarding the impact of two important factors defining American political discourse: traditional party's ideology raising from G. Lakoff's "moral policy" theory and current social situation in the country. The paper suggests a quantitative content analysis of lexical units referring to a particular topic in election speeches of nominees from Republican and Democratic political parties. Quantitative data has been delivered through calculation of these units in the separate corpus compiled from each candidate's speeches. The ratio of the lexical units belonging to particular thematic cluster to the total word-stock in every corpus provides information about important issues in each's candidate programs and their ranking. The position of a certain topic in the rank and its ideology affiliation provides the information about the nature of each's candidate communicative strategy in particular and 2012 political discourse in general.
\end{abstract}

Keywords: political discourse, quantitative content analysis, moral policy theory, lexical units.

Introduction. The USA election process is significantly influenced by two major factors. The first one is the triggering process of cognitive patterns in voter's mind. This aspect is important because being a part of a certain social and cultural group a man sets particular mind filters able to admit information complying with his/her inner values and block contradicting one. In the sphere of American bipartisan political structure, this factor is reflected in form of historically established particular sets of issues, topics and party's attitude towards these issues, which in its turn is realized at the discourse level defining political party's communicative strategy, language means, and vocabulary choice. This has led to appearing of two big traditional political identity groups among citizens: Republican and Democrat supporters though some percentage of floating voters have always been present. The fact of traditionally supported issues plays an important role in bipartisan political competition since if representatives of different parties have similar attitudes towards the same problem, the voter chooses the one whose political party traditionally supports this issue [11].

Another important factor influencing voters' decision is the current political, social, and economic situation in the country [7]. This factor is based on citizens' satisfaction with living standards and political stability. It is outlined by the incumbent candidate's political party affiliation, decisions and actions made for improvements, and period left to the election day [3.]. This factor's impact is less noticeable when social situation is stable and nation's wealth is growing and more noticeable when situation in the country is getting worse.

Purpose. The 2012 Presidential campaign was held on the background of 2008 recession with slow economic growth, high unemployment rates, and the highest ever since the World War II budget debt [1]. Besides, the general situation was tense due to instability in the Middle East region and preparation of withdraw of American troops from Afghanistan. In such a situation, representatives of competing political parties and their camps needed to balance their political agenda considering these two factors in order to design effective election strategy. Given research aims at conducting quantitative content analysis of lexical units referring to a particular thematic clus- ter to find out the most popular issues in each candidates' speeches and therefore to define the prevailing factor in the 2012 Presidential campaign.

Background. Actualization of certain cognitive model makes the basis for political discourse strategy. Human thinking is conditioned by a metaphorization process which categorizes reality into corresponding conceptual systems [10]. The basic cognitive structure of political discourse grounds on the fact that American people's concept system of a family is reflected in the political sphere in a metaphor "the nation as a family" with the government in a parent role and citizens in a role of children [9]. This metaphorical representation of American society projects moral values of American family on the state management sphere. Such an approach unites large groups of people with certain political vision granting compliance with particular social norms and understanding of basic values of American nation.

The main difference between Republican and Democratic cognitive political models lies in projecting the role of the government and, therefore, outlines the discourse of every party. According to G. Lakoff, Republican moral politics is built on traditional patriarchal family model run by a "strict father" who takes care of well-being and safety of his kids growing in the world full of evil [9]. This approach celebrates such Christian family values as diligence, discipline, responsibility, accountability, thrift etc.

In the system of political worldview of Republican Party, this approach is reflected in the relations between the government and citizens. The government provides Americans with equal possibilities, protects them from inner and outer threats but does not interfere into their life once they have "grown up". Those hardworking and disciplined ones will become worthy Americans if they follow traditional moral principles. That is why Republicans traditionally support free market competitive economy, private enterprising, and military preparedness. This serves the reason why they disapprove tax rise and social programs.

The democratic moral politics is based on the "nurturant parent" family model. This family model has no vivid leader, both parents are equally responsible for bringing up, education, and well-being of the "children" [9]. This 
view presents the world as a great place where everyone's duty is to make it better. Mutual care, all-round development, living in harmony with environment, respect, and perception of different values are main principles of such a family. In political framework of Democratic Party, this view is realized through tolerating of unconventional family values, granting state care for all social groups, providing equal rights and opportunities for every citizen. That is why health care, environment, and social protection have always been democratic main issues.

Certainly, there is no straight line dividing American society in two distinctive groups. Most people share both sets of values depending on their own background, social environment, and particular field of activity. As G. Lakoff states, most voters "carry some part of both parental frames in the synapses of their brains; which model is 'activated' - that is, which they can better relate to depends on the language that politicians use and the story that they tell" [2].

Ideological differences in political programs of two big competing powers have been projected into their communicative strategies. Language polarization in American political discourse started in 1990-s and completely shaped in 2007-2009 [6]. Lakoff's "moral policy" theory's insights have been empirically confirmed by researches of A. Cienki [4], G. Deason and M. H. Gonzales [5]. Elements of moral policy model are mainly reflected in a certain set of thematic issues and are realized through corresponding lexical units referring to those fields. Statistical data confirms Lakoff's theory concluding that republican party's prevailing issues were war, defense, and foreign policy while democrat's issues were health care, environment, and social protection [12]. Economic cluster has no clear bipartisan identity and is defined by certain position towards issues such as employment, business, budget, regulation, taxes etc.

Methods and materials. A quantitative content analysis has been conducted to find out prevailing thematic clusters in speeches of competing candidates in 2012 Presidential campaign. The purpose of the analysis is to find out popular topics and calculate respective lexical units. The results enable us to find out the percentage each thematic cluster occupies in the speeches of every candidate demonstrating the importance of every issue for each candidate. Comparison of the obtained results with traditional topics prevailing in political discourse of $\mathrm{Re}$ publican and Democratic Parties will demonstrate whether candidates followed their traditional political agenda or deviated from it in favour of current nation's challenges.

To get detailed data two corpora have been compiled containing samples of 2012 Presidential candidate speeches. The first corpus contains 105 speeches of Democratic nominee Barak Obama with total units volume of 402.343. The second corpus contains 54 election speeches of Republican nominee Mitt Romney with 97739 units in total. Obviously, Obama's corpus has much more units but since the objective of this analysis is to find out a ratio value that particular thematic lexical units take up in the corpus comparing to the overall items, the results are quite representative. The speech samples have been taken from the project "The American presidency" [13]. Technical work on creating the corpora out of speech samples and calculating lexical units has been carried out with the help of special free software tool AntConc.3.4.

Discussion. Through the process of registration of words belonging to a particular thematic field, 13 clusters prevailing in candidates' speeches have been identified. To achieve comprehensive results, the conducted content analysis has covered general lemma forms not taking into consideration separate word forms and word combinations. The received data analysis and comparison have enabled to trace similarities, differences and general tendencies in each candidate's corpus of speeches.

Obama's corpus analysis has demonstrated that economic issues were the most popular in his speeches. The percentage of lexical units referring to this cluster accounts for more than half $(4.8 \%)$ out of all specialized units $(9.5 \%)$ (Table 1). Units referring to domestic and foreign political issues have occupied the second place $(1.8 \%)$ in his speeches indicating the importance of political sphere for the incumbent president. These two themes have largely prevailed over the rest ones in the list. The table shows that about $1 \%$ of his narrative has been devoted to issues of education $(0.9 \%)$ and war conflicts $(0.8$ $\%)$. Less sufficient part in Obama's speeches is occupied by health care and environment thematic clusters $(0.4 \%)$. Science has accounted for only $0.2 \%$. The rest of the list make less than $0.1 \%$ placing these issues beyond incumbent president's priority list.

Table 1. Thematic clusters in B. Obama's election speeches

\begin{tabular}{|l|l|l|l|}
\hline Rate & Thematic cluster & $\begin{array}{l}\text { Lemmas } \\
\text { quantity }\end{array}$ & $\begin{array}{l}\text { Ratio to the overall } \\
\text { corpus units }\end{array}$ \\
\hline 1 & Economics & 14086 & $4.8 \%$ \\
\hline 2 & Politics & 5438 & $1.8 \%$ \\
\hline 3 & Education & 2554 & $0.9 \%$ \\
\hline 4 & War & 2271 & $0.8 \%$ \\
\hline 5 & Health care & 1182 & $0.4 \%$ \\
\hline 6 & Environment & 1095 & $0.4 \%$ \\
\hline 7 & Science & 667 & $0.2 \%$ \\
\hline 8 & Social issues & 542 & $0.04 \%$ \\
\hline 9 & Agriculture & 101 & $0.03 \%$ \\
\hline 10 & Media & 74 & $0.03 \%$ \\
\hline 11 & Sport & 30 & $0.01 \%$ \\
\hline 12 & Law & 18 & $0.006 \%$ \\
\hline 13 & Religion & 10 & $0.003 \%$ \\
\hline & Total & 28068 & $9.5 \%$ \\
\hline
\end{tabular}

Top list analysis demonstrates that among Obama's six most discussed issues traditional democratic topics (except education) occupy the bottom of the list. Although education is among the priority issues, it still has taken only the third position. Politics and war issues generally considered to be republican's domain have been within Obama's priority range. This situation suggests that the incumbent president digressed from classic democratic discourse pattern engaging more into issues that disturbed American people. Although economic cluster has no distinct party identity, the fact this topic heavily prevails in Obama's speeches on the background of difficult economic reality supports previous conclusions. The 2012 incumbent president's speeches results show that B. Obama clearly understood social, economic, and political challenges for the state and chose it his priority in his Presidential campaign.

Mitt Romney speeches analysis has demonstrated that the Republican Party's representative has applied more 
ideology consistent approach. The first place though in close proximity to politics is occupied by economics $(4.35 \%)$. The second and the third places are taken by two conventional to republican camp issues of domestic and foreign political affairs (4. $34 \%$ ) and war issues accounting for $1 \%$ of overall lexical units used in the corpus. Spheres of education and health care have been represented less sufficiently but outnumbered the rest of thematic cluster in the list (Table 2).

Table 2. Thematic clusters in M. Romney's election speeches

\begin{tabular}{|l|l|l|l|}
\hline Rate & Thematic cluster & $\begin{array}{l}\text { Lemmas } \\
\text { quantity }\end{array}$ & $\begin{array}{l}\text { Ratio to the overall } \\
\text { corpus units }\end{array}$ \\
\hline 1 & Economics & 3126 & $4.35 \%$ \\
\hline 2 & Politics & 3121 & $4.34 \%$ \\
\hline 4 & War & 731 & $1 \%$ \\
\hline 5 & Education & 330 & $0.5 \%$ \\
\hline 6 & Health care & 206 & $0.3 \%$ \\
\hline 7 & Law & 157 & $0.2 \%$ \\
\hline 8 & Recial issues & 132 & $0.2 \%$ \\
\hline 9 & Science & 76 & $0.1 \%$ \\
\hline 10 & Sport & 66 & $0.09 \%$ \\
\hline 11 & Environment & 46 & $0.06 \%$ \\
\hline 12 & Agriculture & 25 & $0.05 \%$ \\
\hline 13 & Media & 16 & $0.03 \%$ \\
\hline & Total & 8065 & $11.22 \%$ \\
\hline
\end{tabular}

Romney's top list analysis shows that his top three priority issues were economics, politics, and war conflicts. Taking into account ideology-neutral status of economic cluster, one can conclude that Romney's strategy was more consistent from perspective of moral policy theory. However, high percentage of economic lexis in his speeches indicates the importance of this issue in 2012 election strategy. Judging from quantitative results, Mitt Romney was aware of difficult economic situation in the country and used this factor to weaken the incumbent president's position and demonstrate his care for American citizens. However, it is worth noticing that issues of education and health care go right after top list accounting for $0,5 \%$ and $0,3 \%$ respectively. Although these topics are not considered to be Republican traditional domain, they occupied an important position in Romney's 2012 Presidential campaign indicating their importance to the candidate.

The ranking of other issues in corpora of two candidates differs substantially reflecting Lakoff's moral policy theory. Except politics and war conflicts, the position of the rest of Obama's issues follow conventional democratic ideology. Health care, environment, science, and social issues have traditionally been an important part of Democratic political program. Law and religion prove to be of little importance for Barak Obama during 2012 campaign. These results go in line with the framework of "nurturant parent" family model. Care for all members of society, technological development, and attempts to make the world around better are the core principles of nurturant family. Its members are not so strict about the law, they believe in a good nature of a human being as well as support individual religious freedom. The quantitative content analysis of Democratic Party candidate's speeches in 2012 Presidential campaign generally supports Lakoff's insights of traditional cognitive models in American politics. However, the scope of priority topics for Obama goes beyond the model outlining hopes and challenges of American nation at that period.

The items in the Romney's list following the top five issues prove that he followed Republican Party's traditional scenario in general. The law domain goes before social problems and religion stands before science and environment. This fully reflects "strict father" family model: the members should follow the excepted rules and be obedient parishioners. Everyone should work hard and bear personal responsibility for his or her wellbeing. If anyone faces difficulties, it is because he or she does not follow the rules and needs punishing not help. Environmental problems are of little importance for busy and industrious family members. This picture lies perfectly within the conventional political framework of the Republican Patry - support for traditional family values and enterprising but rejection of environmental and social programs.

Conclusion. The 2012 US Presidential campaign was held at the time of serious internal and external challenges for American nation. The majority of American citizens still felt the results of 2008 economic recession. The society was worried by low rate of economic growth and high level of unemployment. Banking system was recovering slowly and medical care system evoked countless disputes over its efficiency. These issues worried an average American citizen and, therefore, demanded reaction from both candidates making them find a balance between their parties' traditional political agenda and current issues.

The analysis of lexical units belonging to a particular thematic cluster in each's candidate corpus has demonstrated that both candidates generally followed the traditional ideological political patterns though with some exceptions. Mitt Romney seemed to be more consistent in his speeches. Among three most frequently discussed topics no issues referring to the conventional sphere of competing party have been found. The rest of the lexical units accounting for less than $2 \%$ of all words in the corpus belonged to different thematic clusters. Issues traditionally considered to be the Democratic Party's priority have been represented in the list. Education and health care have occupied quite a big part comparing to the rest of thematic clusters. However, their presence in the republic candidate's list do not change the overall picture since Lakoff's theory do not reject presence of other's party dominant issues but highlights the priority level [9].

Barak Obama's speeches analysis has demonstrated deviation from the traditional Democratic Party ideology agenda. Top three list of most important issues has got one topic without clear party identity (economics), one topic conventionally associated with the Republican Party (politics), and one issue with conventional Democratic Party affiliation (education). The rest of the list of important topics generally follows the traditional democratic ideological pattern though with the war issues on the top. Regarding the priority issues ranking in Obama's speeches, one can conclude that his communicative strategy did not follow the moral policy theory and the factor of current challenges overtook the factor of traditional topics of the Democratic Party candidate.

The overall results shows that the priority for both candidates was the economic situation in the USA in 2012. 
This topic has taken the first place in the Mitt Romney's speeches leaving behind political issues. However, the difference is too small to conclude that economics was his major domain. As non-incumbent candidate, he definitely used this topic not only to persuade voters but also to criticize his opponent. On the opposite, Barak Obama defined this topic as an absolute priority using almost the same amount of economic terminology than words referring to the rest 12 thematic clusters. Being an incumbent president he realized the importance of American people's wellbeing and put most effort to persuade that his economic program was moving in the right direction.

\section{REFERENCES}

1. Amadeo, K. (2019). US Economy 2012: Summary and Critical Events. The Balance. Retrieved from https://www.thebalance.com/u-s-economy-2012-3305742.

2. Bai, M. (July 17, 2005). The Framing Wars. New York Times Magazine. Retrieved

from https://www.nytimes.com/2005/07/17/magazine/the-framingwars.html.

3. Campbell, J. E. (2019). Evaluating U.S. Presidential Election Forecasts and Forecasting Equations. International Journal of Forecasting, 24, 259-271. Retrieved from https://www.acsu.buffalo.edu/ jcampbel/documents/IJF7Cam pbell.pdf.

4. Cienki, A. (2005). Metaphor in the "Strict Father"' and "Nurturant Parent" Cognitive Models: Theoretical Issues Raised in an Empirical Study. Cognitive Linguistics 16, 279-312.

5. Deason G., Gonzales M. H. (2012). Moral Politics in the 2008 Presidential Convention Acceptance Speeches. Basic and Applied Social Psychology 34, 254-268.

6. Gentzkow, M., Shapiro, M., and Taddy, M. (2019). Measuring Group Differences in High-Dimensional Choices: Method and Application to Congressional Speech. Stanford University. $\quad$ Retrieved from http://web.stanford.edu/ gentzkow/research/politext.pdf.
7. Iyengar, S. (2005). Speaking of Values: The Framing of American Politics. The Forum 3, 3. Retrieved from https://doi.org/10.2202/1540-8884.1093.

8. Lakoff George. (2004). Don't Think of an Elephant! Know your Values and Frame the Debate. White River Junction: Chelsea Green Publishing.

9. Lakoff George. (2016). Moral Politics: How Liberals and Conservatives Think. Chicago: The University of Chicago Press.

10. Lakoff G., and Johnson M. (2008). Metaphors We Live by. Chicago: University of Chicago Press.

11. Owen, G., Goodliffe, J., Herrnson, P., and Patterson, K. (2003). Agenda Setting in Congressional Elections: The Impact of Issues and Campaigns on Voting Behavior. Political Research Quarterly 56, no. 4, 419-430. Retrieved from https://www.jstor.org/stable/3219803?readnow $=1 \&$ seq $=1$ \#page_scan_tab_contents.

12. Sulkin, T., Moriarty, C., and Hefner, V. (2007). Congressional Candidates' Issue Agendas On- and Off-line. The International Journal of Press/Politics 12, no. 2, 63-79.

13. The American Presidency Project. Retrieved from http://www.presidency.ucsb.edu. 